This item was submitted to Loughborough's Research Repository by the author.

Items in Figshare are protected by copyright, with all rights reserved, unless otherwise indicated.

\title{
A review of pumped hydro energy storage development in significant international electricity markets
}

PLEASE CITE THE PUBLISHED VERSION

https://doi.org/10.1016/j.rser.2016.04.019

\section{PUBLISHER}

(C) Elsevier

VERSION

AM (Accepted Manuscript)

\section{PUBLISHER STATEMENT}

This work is made available according to the conditions of the Creative Commons Attribution-NonCommercialNoDerivatives 4.0 International (CC BY-NC-ND 4.0) licence. Full details of this licence are available at: https://creativecommons.org/licenses/by-nc-nd/4.0/

\section{LICENCE}

CC BY-NC-ND 4.0

\section{REPOSITORY RECORD}

Barbour, Edward, I.A. Grant Wilson, Jonathan Radcliffe, Yulong Ding, and Yongliang Li. 2019. "A Review of Pumped Hydro Energy Storage Development in Significant International Electricity Markets". figshare. https://hdl.handle.net/2134/36991. 


\section{A review of Pumped Hydro Energy Storage development in significant international electricity markets}

Edward Barbour ${ }^{\mathrm{a}, *}$, I.A. Grant Wilson ${ }^{\mathrm{b}}$, Jonathan Radcliffe ${ }^{\mathrm{a}}$, Yulong Ding ${ }^{\mathrm{a}}$ and Yongliang Li ${ }^{\mathrm{a}, \S}$

${ }^{a}$ Birmingham Centre for Energy Storage, The University of Birmingham

${ }^{b}$ Environmental and Energy Engineering Group, Department of Chemical and Biological

Engineering, The University of Sheffield

*corresponding author: edward.r.barbour@gmail.com

${ }^{\S}$ corresponding author: y.li.1@bham.ac.uk

\section{Abstract}

The global effort to decarbonise electricity systems has led to widespread deployments of variable renewable energy generation technologies, which in turn has boosted research and development interest in bulk Electrical Energy Storage (EES). However despite large increases in research funding, many electricity markets with increasingly large proportions of variable renewable generation have seen little actual bulk EES deployment. While this can be partly attributed to the need for technological developments, it is also due to the challenge of fairly rewarding storage operators for the range of services that storage provides to the wider network, especially in markets that have undergone significant restructuring and liberalisation. Pumped Hydroelectric Energy Storage (PHES) is the overwhelmingly established bulk EES technology (with a global installed capacity around $130 \mathrm{GW}$ ) and has been an integral part of many markets since the 1960's. This review provides an historical overview of the development of PHES in several significant electrical markets and compares a number of mechanisms that can reward PHES in different international market frameworks. As well as providing up-to-date information about PHES, a primary motivation for this work is to provide an overview about the types of rewards available to bulk EES for the wider storage community including investors, technology developers and policy-makers. Observing that bulk EES projects seem to be unattractive investments for the private sector, the paper also includes a brief discussion in terms of public sector investment. 


\section{Introduction}

In the last decade, interest in bulk Electrical Energy Storage (EES) technologies has grown significantly as a potential solution to some of the challenges associated with decarbonising electrical energy systems. The transition from systems that are primarily reliant on carbonintensive fossil fuels to those which use greater amounts of lower-carbon energy sources like renewables and nuclear energy is a broadly accepted policy choice of many countries around the world, although the exact technology choices, the speed of the transition and the level of ambition vary widely. The decarbonisation policies are a response to the compelling evidence around the risks of anthropogenic climate change, and the need to decouple economic growth from environmentally damaging impacts.

One of the greatest challenges of many low-carbon generation technologies is that they lack a similar level of load-following flexibility compared to conventional fossil fuel based power generation. This is especially true of renewable generation that is weather dependent. For example, the wind and solar primary energy resources are variable, often unpredictable (when the forecast window to real time is stretched), and crucially lack the intrinsic energy storage associated with fuel-based generation. Therefore, while weather dependent renewable generation can generally be turned down (curtailed) if demand is low, it lacks load-following flexibility as it cannot be turned up if the primary energy source is unavailable. Simply put, it is not possible to store these primary energy resources, e.g. one cannot store the wind as wind or the sunlight as sunlight. This is a simple but powerful concept as intrinsic energy storage is a defining characteristic of any fuel. Fossil fuels in particular are a major part of the primary energy supply of most electrical systems due to their cost, availability, energy density, ease of storage, ease of handling and ease of transportation. Historically, the low comparative cost of storing electrical energy in fossil fuel stockpiles, prior to its conversion to electricity, has meant that fossil fuel stockpiles are overwhelmingly preferred as the stores of electrical energy [1]. Their use as a source of energy that is converted to electricity as and when required has enabled electrical energy systems to be developed under a 'demand led' paradigm where electrical generation is controlled in order to closely match the demand at any given point in time. 
The limited ability of wind and solar technologies to load-follow is one of the main challenges that bulk EES seeks to address. Several academic studies have highlighted energy storage as an important method of adding the flexibility that is required to integrate large proportions of low carbon energy in electricity networks. An extensive report by Denholm et al. (2010) [2] for the National Renewable Energy Laboratory, USA concludes that high penetrations of variable generation increases the need for all flexibility options, including energy storage. Eyer and Corey (2010) [3] also conclude that renewables integration is one of the major drivers for energy storage while Beaudin et al. (2010) [4] concludes that large scale renewables integration will be a more difficult challenge without energy storage. Steinke et al. (2013) [5] investigates a 100\% renewable Europe and finds that without grid and storage extensions the necessary backup generation amounts to roughly $40 \%$ of the demand. Cochran et al. (2012) [6] study the best practices for integrating variable renewable generation and concludes that while there is no one size fits all approach, market mechanisms that promote increased storage should be developed. Although it is generally accepted that smaller percentages of renewable generation can be integrated into many electricity systems without very significant operational changes [2], [7], the scale of transition required to meet the climate change challenge means that additional flexibility is likely to be universally required. This increasing need for flexibility [8] due to the planned increase in the penetration of variable renewable energy sources is, we believe, a major driver for interest in bulk EES.

The other technologies besides wind and solar which can provide low-carbon electricity on a global scale are nuclear power and fossil fuels with Carbon Capture and Storage (CCS). However, nuclear power also lacks load-following flexibility and historically was deployed alongside significant developments of PHES [9]. This is because frequently turning down the output from nuclear power plants not only increases the electricity cost by reducing the load factor but also strongly accelerates the aging of equipment [10]. Therefore if nuclear is to be deployed in future, without further bulk EES, an important design consideration is loadfollowing ability. This design for flexibility is however likely to increase the cost of the plant, and consequently the cost of the electricity generated from the plant too. On the other hand, CCS technologies have so far failed to gain any meaningful levels of deployment, despite significant research and development [11]. 
The delays in the development and deployment of CCS or more flexible nuclear technologies in comparison to the speed of recent deployments of solar and wind generation is also a major reason why bulk EES has attracted a growing level of interest from public and private funding sources. Bulk EES also has many other benefits throughout the electrical supply chain, and several studies have discussed these [2]-[4], [12]-[15]. They include:

- facilitating increased deployment of low-carbon generation

- facilitating time of use energy management

- increasing reliability for end-users

- reducing the volatility of electricity prices

- $\quad$ increasing system reliability

- $\quad$ increasing system flexibility

- reducing the need for transmission upgrades/new transmission infrastructure

- reducing overall pollutant emissions.

Novel bulk EES technologies under development include Adiabatic Compressed Air Energy Storage (ACAES) [16], secondary (rechargeable) batteries [17], flow batteries [18], Cryogenic Energy Storage (CES) [19], Pumped Thermal Energy Storage (PTES) [20] and Hydrogen energy storage [21].

This paper focuses on the established bulk EES technology Pumped Hydroelectric Energy Storage (PHES), as over 99\% of the existing bulk EES capacity worldwide is PHES, comprising a global installed capacity in excess of $125 \mathrm{GW}$ [9]. Compressed Air Energy Storage (CAES) has the next largest installed capacity of $440 \mathrm{MW}$ with two operational plants; Huntorf, Germany and McIntosh, USA [22], [23]. This paper builds on the paper by Anuta et al. (2014) [24] that provides an extensive review of the regulatory and policy environments relating to energy storage in several countries with high renewable energy targets. Our work complements this by providing an historical context to the development of PHES and an overview of current market environments for PHES in the electricity markets of several countries (UK, USA, Germany, Japan, China, Switzerland and India). Finally we offer a brief observation and conclusion in terms of direct public sector investment. 


\section{Pumped Hydroelectric Energy Storage (PHES)}

PHES stores gravitational potential energy by elevating water. The charging process converts electrical energy into mechanical energy and eventually into gravitational potential energy by pumping water from a lower reservoir to a higher reservoir. The discharging process is the reverse; it converts gravitational potential energy into mechanical energy and then to electrical energy by allowing water to flow down from the higher reservoir to the lower reservoir, driving a turbine that in turn drives an electrical generator. Table 1 gives some of the typical technical characteristics of PHES plants and Table 2 shows several of the countries with the largest installed PHES capacities.

Table 1: Technical characteristics of PHES. Information obtained from [4], [12], [13]

\begin{tabular}{|l|l|}
\hline Power & $10-4000 \mathrm{MW}$ \\
\hline Discharge duration at rated power & $1-24+$ hours \\
\hline Round-trip efficiency & $70-85 \%$ \\
\hline Self-discharge & Generally negligible \\
\hline Response time & Minutes \\
\hline Power capital cost & $2000-4300 \$ / \mathrm{kW}$ \\
\hline Energy Capital cost & $5-100 \$ / \mathrm{kW}$ \\
\hline Lifetime & $40-60+$ years \\
\hline Suitable storage duration & Hours - days \\
\hline
\end{tabular}

Table 2: Installed PHES capacity by country and current (2014) capacity under construction. Percentage of total installed generation corresponding to PHES is also given. Data compiled from [9], [25]-[28].

\begin{tabular}{|l|l|l|l|}
\hline Country & $\begin{array}{l}\text { Installed PHS } \\
\text { Capacity (GW) }\end{array}$ & $\begin{array}{l}\text { Under } \\
\text { Construction } \\
(\mathrm{GW})\end{array}$ & $\begin{array}{l}\text { PHES power capacity as a \% } \\
\text { of installed electrical } \\
\text { generating capacity }\end{array}$ \\
\hline Japan & 24.5 & 3.3 & 8.5 \\
\hline China & 22.6 & 11.6 & 1.8 \\
\hline USA & 20.5 & - & 1.9 \\
\hline Italy & 7.1 & - & 5.7 \\
\hline
\end{tabular}




\begin{tabular}{|l|l|l|l|}
\hline Spain & 6.8 & - & 6.6 \\
\hline Germany & 6.3 & - & 3.5 \\
\hline France & 5.8 & - & 4.4 \\
\hline India & 5.0 & 1.7 & 2.2 \\
\hline Austria & 4.8 & 0.2 & 21 \\
\hline Great Britain & 2.7 & - & 3.0 \\
\hline Switzerland & 2.5 & 2.1 & 12 \\
\hline Portugal & 1.1 & 1.5 & 6.1 \\
\hline
\end{tabular}

At a country level Japan has the largest installed capacity of PHES at 25GW [25], which represents over $8.5 \%$ of its installed electricity generating capacity. China has the second largest capacity of PHES followed by the USA, however PHES constitutes only 1.8\% and 1.9\% respectively of their total installed electric generation capacity.

\subsection{Historical development of PHES}
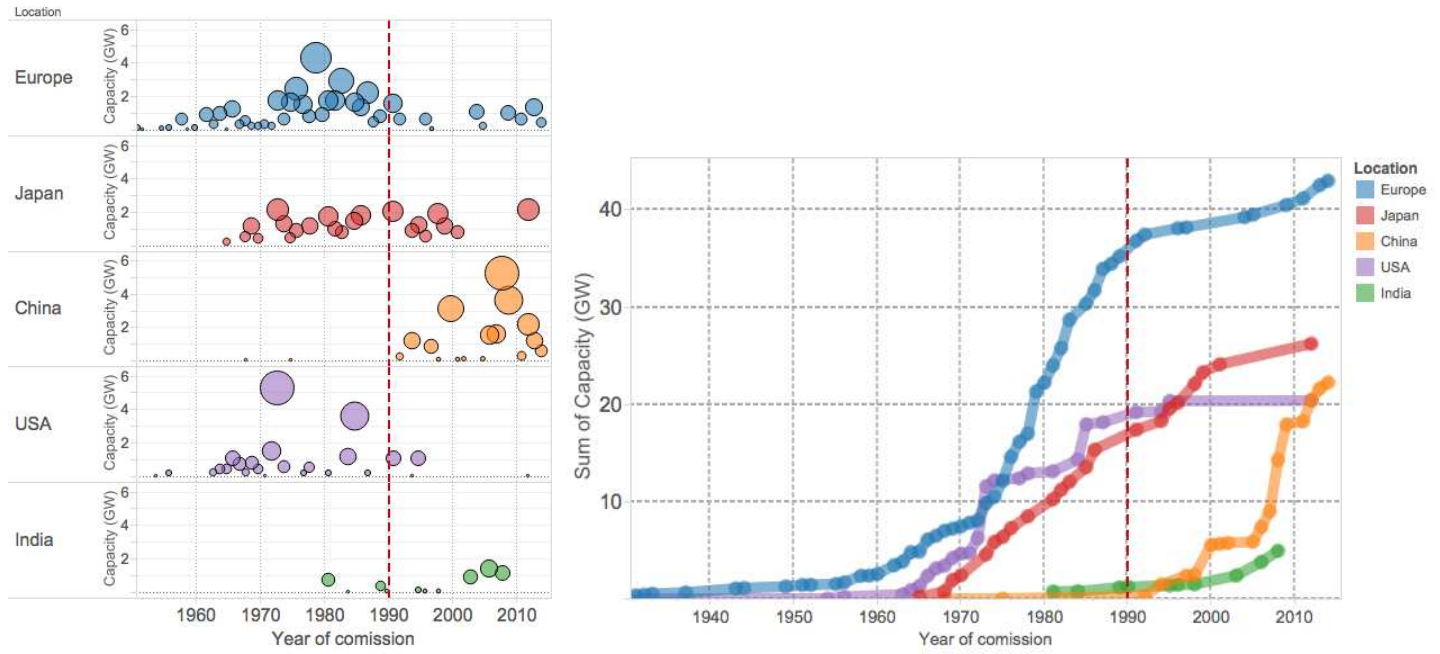

Figure 1: (left) Historical PHES deployment in Europe ${ }^{l}$, Japan, China, USA and India (GW). The dots represent each year in which at least one PHES plant was commissioned, and have an area proportional to the capacity commissioned in that calendar year. (right) Cumulative sum of PHES deployment power capacity (GW). The list of PHES plants included is available to download [29].

\footnotetext{
${ }^{1}$ Europe in Figures 1 and 2 includes Austria, Belgium, Czech Republic, France, Germany, Ireland, Italy, Luxembourg, Norway, Poland, Portugal, Spain, Switzerland, and the UK.
} 


\subsubsection{Europe}

Figure 1 shows that Europe has the most PHES capacity and that over $80 \%$ of it was commissioned between 1960 and 1990. The majority of the schemes are located in the mountainous regions of Austria, France, Germany, Italy, Spain and Switzerland. Although in many countries development was aligned with significant increases in nuclear capacity, some countries like Austria installed significant PHES capacities despite having no nuclear power at all. As Figure 1 shows, the rate of development of PHES in Europe has slightly increased since 2008, which is thought to have been a response to the increasing energy demand during the 90's and early 2000's (PHES projects have long construction times) and anticipation of increased wind generation. The 430 MW Reisseck II scheme in Austria (commissioned in 2014) and the expansion of the Spanish La Muela pumped storage facility by 852 MW (in 2013 - giving it a total capacity in excess of 2GW) are some of Europe's most recent PHES developments [30].

\subsubsection{Japan}

Japan has historically developed PHES to compliment its nuclear generation, and to provide an alternative to fossil fuelled peaking plants. With very modest indigenous fossil fuel resources (Japan imports 95\% of its primary energy supply [31]), Japan chose nuclear power as a major source of electricity generation. The preference to use nuclear generation as a baseload technology means that it couples well with flexible plants, like gas or hydroelectric generation. For energy security reasons Japan has opted for a large capacity of PHES to complement its nuclear power and provide peak electricity. In addition, it also has no electrical interconnections with other countries (unlike France for example, which is a large exporter of nuclear-generated power to the UK, Germany, Italy, Switzerland and Spain). This adds to the value of flexible generating plants and gives one reason why the percentage of PHES capacity is significantly higher than in many other countries. The mountainous interior of Japan is well suited for PHES, although many of the best sites have now been developed. As a result Japan has pioneered a seawater pumped hydro scheme on Okinawa Island [32]. Historically Japan has also had some of the highest electricity prices in OECD countries [24]. It should be noted 
that Japan is actively pursuing other EES storage options and has developed as a leader in sodium sulphur (NaS) grid-scale electrochemical battery installations [33].

\subsubsection{China}

Compared to Europe, the USA and Japan, the development of PHES in China occurred relatively recently (Figure 1). Although the first PHES scheme (11MW) was constructed in 1968 and the second in 1975, development after this remained dormant until the 1990's. Since then it has progressed rapidly for a number of reasons. Electricity consumption has been growing with China's rapid economic development and PHES is seen as particularly useful to bridge the valley-to-peak gap and increase grid-reliability. Governmental and regional targets for carbon reduction have increased the installed capacity of renewable energy, and pumped hydro is regarded as a way to aid integration. The rapid development of wind energy in north and west China with insufficient transmission infrastructure can also be considered as a significant driver for increased PHES development [34]. By the end of 2013, the total installed wind capacity in China was $91.4 \mathrm{GW}$; however the national curtailment rate for wind was $11 \%$, and in some areas this exceeds $25 \%$ at certain times [35]. China's high share of coal based power generation is another driver for more flexible generation, as most plants are large scale (>300MW) and less efficient and less economic to operate at partial load (the economic factors are exaggerated by high coal prices). The increase in PHES capacity is occurring alongside significant expansions of conventional hydro generation (China has over $280 \mathrm{GW}$ of installed Hydro as of 2013) [36].

\subsubsection{USA}

As in Europe, the majority of PHES plants in the USA were constructed in the period 1960 1990 [9]. This period was aligned with significant increases in nuclear capacity and also the energy crisis of the 1970's [9]. Denholm et al. (2010) [2] observe that the large increases in the price of oil and gas in the 70's along with uncertainty about future prices led utilities in the US to evaluate PHES (along with other storage technologies) as alternatives to fossil fuel peaking units. With lower electricity costs $(\$ / \mathrm{kWh})$ for PHES plants (charging using nuclear or coal) than oil or gas peaking plants and similar capital costs $(\$ / \mathrm{kW})$ at this time, PHES was often more attractive economically. This approach largely ignored the additional operational 
benefits that EES can provide [2]. Subsequent decreases in the price of oil and gas as well as large decreases in the capital costs of Combined Cycle Gas Turbine (CCGT) peaking units then led to a hiatus in energy storage interest and since 1990 there has been minimal deployment of PHES in the USA. This is not thought to be due to a lack of suitable sites; some articles have suggested that the USA has a PHES potential greater than $1000 \mathrm{GW}$ [9].

\subsubsection{India}

In India the first pumped storage plant was the 770 MW Nagarjunasagar plant which was fully commissioned in 1981. Between 1981 and 1998 a further 742 MW of PHES was added, and an additional $3450 \mathrm{MW}$ was added between 2003 and 2008 (the ninth and tenth five year plans of the Wholesale Electricity Market of India (WEMI) [37]). The motivation to use pumped hydro in India comes primarily from the desire to meet peak electrical demand; the peak power capacity is short of the peak demand in most states by $10-15 \%$. The aim for pumped hydro plants is therefore to shift electricity from off-peak to peak hours. However most PHES plants have been unable to perform to their full potential due to insufficient availability of offpeak electricity, which is often less than the pumping capacity of the plants [37]. This has meant that many mixed PHES stations have achieved much less than their designed pumping time, and thus their energy output has been lower than projected.

\subsection{Market status at commissioning}

Figure 2 shows the capacity (in GW) of PHES that has been commissioned in different market environments in the review regions. We find that over $95 \%$ of PHES came into existence under monopoly market conditions; either a national or regional monopoly or even a regional monopoly that is open to independent power producers such as exists in China and India today. Less than $5 \%$ of PHES capacity (only $4.9 \mathrm{GW}$ out of a total installed capacity of $117 \mathrm{GW}$ ) in the regions under review was commissioned in liberalised market conditions. 


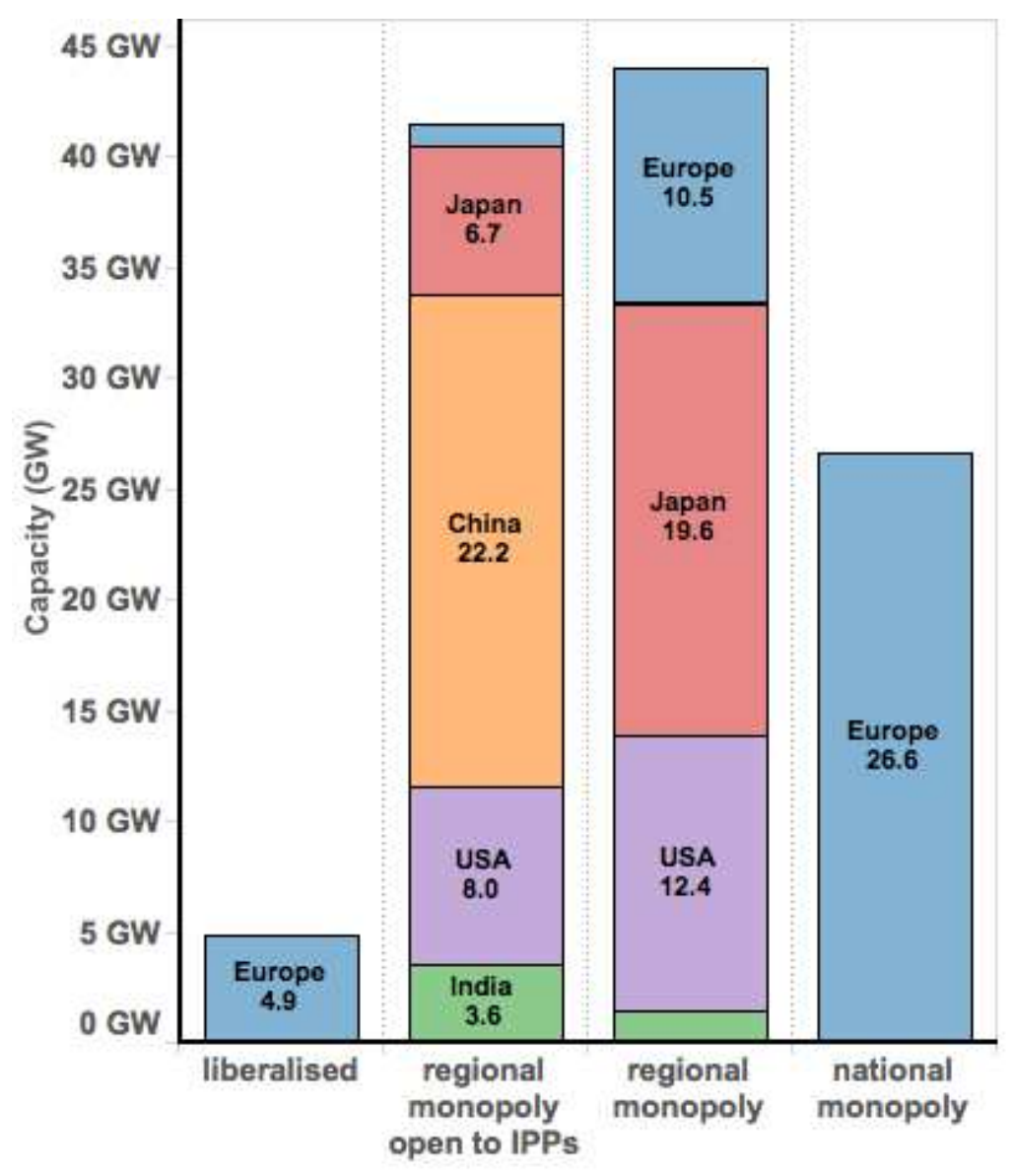

Figure 2: Capacity (GW) of PHES commissioned under different market structures.

\subsection{Current ownership of PHES}

We find that the largest owner of PHES capacity (in GW) is the State Grid Corporation of China, with over $15 \mathrm{GW}$ of pumped storage capacity. Tokyo Electric Power Corporation has the next largest capacity and operates in Japan, while ENEL has the largest capacity in Europe and owns PHES plants in both Italy and Spain (through its majority stake in the Spanish Utility Endesa). Table 3 shows the ten largest owners of PHES on a GW basis.

Table 3:Ownership of PHES on a per GW basis and number of plants

\begin{tabular}{|l|l|l|l|}
\hline Ownership company & Location & $\begin{array}{l}\text { Number of } \\
\text { plants }\end{array}$ & $\begin{array}{l}\text { Total Installed } \\
\text { Capacity (GW) }\end{array}$ \\
\hline SGCC & China & 17 & 15.2 \\
\hline ENEL & Europe & 24 & 8.3 \\
\hline Tokyo EPCO & Japan & 9 & 7.3 \\
\hline EDF & Europe & 12 & 6.2 \\
\hline
\end{tabular}




\begin{tabular}{|l|l|l|l|} 
J-Power & Japan & 7 & 5.0 \\
\hline Kansai EPCO & Japan & 4 & 4.9 \\
\hline CSPSG & China & 3 & 4.9 \\
\hline Iberdrola & Europe & 11 & 4.9 \\
\hline GDF Suez & Europe \& USA & 8 & 4.7 \\
\hline Chugoku EPCO & Japan & 5 & 3.2 \\
\hline
\end{tabular}

It should be noted that as many markets have been partially or fully liberalized the ownership of the PHES schemes can readily change. It is not possible to understand with any clarity the 'market' price with which many of these PHES schemes changed hands, as they were in many cases part of a larger bundle of assets. Table 3 only reflects ownership that current data suggests. 


\section{PHES revenue mechanisms in different markets}

\subsection{Main revenue classes for Energy Storage}

There appear to be three broad classes of revenue model under which EES can operate in an electricity market. A specific bulk EES scheme may include aspects from all of these classes; however for explanatory purposes it is useful to broadly classify the models in this manner. A fuller description of business models for energy storage and risk mitigation aspects is given in Masiello et al. (2014) [38].

\subsubsection{The 'cost-of-service' business model}

In this business model the cost of a project is remunerated in a regulated manner, typically to cover the cost of the project's operating costs plus an agreed (with the regulator) rate of return on the project's capital costs. This is a business model that would be common for a monopoly provider operating in either an unbundled liberalised market or a non-liberalised market with little or no unbundling. Although this model is frequently used for Transmission or Distribution infrastructure in unbundled liberalised markets, regulators have been reluctant to adopt it for EES due to the concern that EES could also derive revenue in the competitive part of the market too, which they rightly conclude could provide an unfair advantage. However, it also seems perverse that if bulk EES, or for that matter more distributed energy storage, is used as a transmission/distribution asset it should not be managed and remunerated in a regulated manner. Therefore the challenge is finding a policy mechanism that provides investment in energy storage but manages to curb the potential for market abuse.

\subsubsection{Direct participation in a competitive market}

In the competitive part of a liberalised electricity market an EES operator would have to compete with other market participants (unless special treatment is afforded by policy). Typically PHES schemes derive part of their revenue from the time-shifting of electrical energy, by charging at off-peak times when the price is low and discharging at peak times when the price is higher. Their participation then reduces the price spread between off-peak

\footnotetext{
${ }^{2}$ Also termed a 'cost-plus' model
}

11 
and peak slightly (or the price for whichever service they were offering - for example fast reserve, frequency response etc.) and in doing so should increase the global surplus, that is the consumer surplus plus the producer surplus. Consumer surplus is the difference between what consumers would be willing to pay and the market price, and producer surplus is the difference between the market price and the price they would be willing to accept (for a rigorous description of these concepts in power markets see [39]). This market participation could include entering long term Power Purchasing Agreements (PPA's) with other market players and/or contracting services to other market players [24].

Ultimately this model relies on EES being able to provide competitive market-services at a similar or better level than the alternatives. However, market based incentives can be introduced by policy to encourage investment in certain technologies, as is the case with renewable incentives in the EU [40], [41] and the USA, to encourage the deployment of renewable generation at different scales. Arguably, market based incentives could also be developed for bulk EES too. It is worth noting that deployment with incentives reaches scale only after a period of successful R\&D investment has proven fruitful in actually delivering technologies worth deploying [42]. The deployment at scale then accelerates modular technologies down their cost-curves and provides a virtuous spiral of decreasing costs through learning. With this type of reasoning, Germany has already introduced an energy storage subsidy for residential batteries up to $30 \mathrm{~kW}$ [43]. In the case of PHES however, the costs are biased towards civil engineering that is determined on a project-by-project basis, and so the scope to reduce costs along the supply chain may seem rather limited.

\subsection{3. 'Behind-the-meter' energy storage}

This model applies to energy storage located on the generator's/consumer's/end-user's side of the electricity meter, private wire and off-grid energy storage applications. In this case the generator/consumer/end-user would analyse their own localized energy needs and economics to determine the viability of the storage unit. This could depend on inter alia the available energy-tariffs, any renewable incentives, the value of increased reliability and/or the perceived value of increasing the consumers own renewable energy use. A behind-the-meter energy storage device could also theoretically participate in the competitive electricity market 
provided there were no regulatory barriers to market entry from this point (for example as a form of demand response). An example of a hybrid model of 'behind-the-meter' and 'competitive market participation' would be the case of an EES plant which was part of a single large utility's generation portfolio, used not only to offer market services but also as an internal balancing and trading mechanism.

\subsection{Difficulties with rewarding EES in electricity markets}

Despite large recent increases in research and development funding for bulk EES, new investment in bulk EES in the liberalised markets reviewed in this paper has been limited, including those where the proportion of renewable generation has markedly increased. The investment in recent years in PHES has mainly happened in the markets that are still under public ownership. A major reason for this is thought to be due to the regulatory and financial uncertainty surrounding the integration of PHES into liberalised electricity markets, which increases the risk, without providing the certainty of rewards over longer-time frames. This is a necessary pre-condition of attracting private sector investment into high capital cost longlived assets such as PHES. There is also little international agreement on the optimal policies to incentivize investment in PHES, optimal PHES operational strategies or indeed even which entities should be able to own and operate bulk energy storage. This is not necessarily surprising given PHES's varied benefits to stakeholders across the electrical system [3], [12] and the range of different markets, international generation mixes and demand profiles that exist.

In unbundled liberalised electricity markets, providing the policies and mechanisms to correctly reward PHES seems especially difficult, as the benefits of storage span across both competitive and regulated-monopoly non-competitive market sectors [44], a classic split incentive problem. In addition, many of these benefits are in the form of 'avoided costs', and so in order for the storage operator to benefit financially either they must themselves be the bearer of a large enough proportion of these costs or there must exist some mechanism to transfer part of the savings from other market actors to the PHES operator. Licensing conditions in unbundled markets often preclude or restrict the ownership and operation of EES in non-competitive market areas, where many benefits of EES may be available [3]. For 
example, an energy storage device may introduce a cost saving for a Transmission or Distribution company, by avoiding the purchase of additional Transmission/Distribution (T/D) infrastructure or may relieve conventional start-shut cycles of thermal generators in the grid [45], reducing their operating costs to utilities. These licensing restrictions are predominantly due to concerns mentioned previously that bulk EES could be used as both a regulated asset and simultaneously participate in the competitive market. There may be contractual third party avenues around this ownership issue, but as yet they are not widespread and there is concern that this kind of approach would potentially add an additional layer of legal costs and uncertainty to maneuver around regulation that is fundamentally not suited to bulk EES.

These types of difficulties present barriers to the development of novel energy storage technologies as EES technology developers are often unsure of the performance and capital costs that they need to achieve to make their technologies attractive propositions to potential investors.

\subsection{International markets and mechanisms}

\subsubsection{Great Britain}

In the market in Great Britain (GB), PHES operates as part of an unbundled liberalised electricity market, competing to provide market services. Legislation prevents Transmission or Distribution companies from owning energy storage (or other generation) assets; of the four PHES plants in Great Britain, one each are owned under the generation arm of two separate utilities and a further two schemes are owned by a single merchant operator (First Hydro which is a subsidiary of GDF Suez, a French multinational electric utility company). Data from the National Grid (the Transmission Network Operator) suggests that these plants offer ancillary services such as frequency response and fast reserve and information from the utilities suggest they also participate in energy arbitrage and provide black-start capacity [46]. A handful of academic studies have examined the potential of PHES to generate revenue via time-shifting arbitrage in the GB market, and have generally concluded that there is insufficient revenue potential from arbitrage alone to warrant investment. Using the algorithms developed by Barbour et al. (2012) [47] and Connolly et al. (2011) [48], we find that a 300 MW 1800 MWh 75\% efficient PHES scheme in the GB market could have made a maximum 
of $£ £$ million in 2013 via arbitrage with perfect price forecasting. For further information please refer to these articles; source code for the models is also available to download [29]. Such a scheme in the UK may have a capital cost in excess of $\sim £ 400$ million (SSE recently proposed a $600 \mathrm{MW}$ scheme in Coire Glas for $£ 800$ million [49]), implying a payback in excess of 40 years if used for arbitrage alone. Dinorwig PHES currently runs two of its turbines (each 300MW) for frequency response, gaining an availability fee $\sim £ 1900 / \mathrm{hr}$ for each turbine (for 109 hours per week, equating to $\sim £ 10.8$ million per year) [50]. Hence even when ancillary services are considered, the payback times for PHES schemes in the UK seem too long to justify significant investments.

The only serious recent interest in PHES in the UK has come from Scottish and Southern Energy (SSE) under their generating arm, who proposed to build a new PHES plant at Coire Glas in Scotland [51]. However this project has not gone ahead due to the high cost of transmission connection charges [52]. It is also worth noting that SSE have a large and diverse power generating portfolio, as does Ibedrola the other utility that owns another pumped storage scheme. Therefore it is likely that the PHES plants can be used to optimize the utilities' own generation operations by internal trading, which may or may not align with providing wider system benefits.

\subsubsection{Germany}

Germany is Europe's largest connected electrical market, and has the largest installed capacity of PHES. It is an unbundled liberalised market with Europe's largest installed wind and solar capacities (around 36GW of solar and $33 \mathrm{GW}$ of wind [53]) and so it is intuitive to expect that it should have a market particularly well suited for EES. Indeed quite recently it was thought that prospects for PHES in Germany were improving due to the large increases in installed renewable energy capacity, having seen little development in the last 20 years. Steffen (2012) [54] described how the prospects of PHES in Germany had improved in 2011 with the announcement of two extensions and 10 new build proposals. However, this article did note that profitability was uncertain. In fact this situation has reversed and currently (as of the beginning of 2015) most proposals have been suspended or abandoned and the prospects for 
PHES in Germany are bleak. This is due to low wholesale German electricity prices that have been driven down by the large amounts of subsidised wind and solar generation. The wind and solar energy produced can be sold cheaply due to the subsidy they receive, thus depressing the wholesale electricity prices whilst simultaneously increasing retail electricity prices. On top of this on sunny days in particular, solar-generated electricity can significantly reduce the number of daytime hours with high prices. This reduces the number of hours during which it is favorable for PHES to discharge. As a result some existing PHES plants cannot operate profitably by providing peak capacity and in the summer of 2014 some German PHES plants were mothballed [55]. This points to somewhat of a perverse policy outcome, as energy storage should be especially valuable in markets with higher penetrations of renewable generation.

It is noted that several factors influence this particular issue of wholesale price movement; Germany's response to the Fukushima disaster was to speed up the phase-out of nuclear power removing a potentially cheaper source of baseload charging energy for PHES. This, coupled with favourable prices for coal and lignite has increased the market share of these generation types, and peak daytime electricity prices have been reduced by the erosion of the market share of natural gas generation by solar PV generation. It is notable the increase in coal use has led to an increase in Germany's $\mathrm{CO}_{2}$ emissions [56].

For those PHES plants that can, taking advantage of more valuable ancillary services is an option. Vattenfall's Goldisthal Pumped Storage Power Station is Europe's first PHES station which uses variable-speed (asynchronous) motor-generators [57]. These are used in two out of the four reversible pump-turbine units and allow the plant to provide regulation services while pumping, as well as increasing efficiency at part-load (which is particularly useful for ancillary service use). Accordingly this plant participates in the reserve markets, providing services like frequency regulation, as well as participating in the energy market.

\subsubsection{Switzerland}

Switzerland lies at the heart of Europe and is unique due to the scale of its large cross-border electricity trade with Germany, France and Italy [58]. The electricity market is partially 
liberalized and has not been fully unbundled; not being an EU member-state Switzerland also does not have to sign up to the EU's competition and liberalization laws. While consumers with a yearly usage above $100 \mathrm{MWh}$ are able to choose their electricity supplier, smaller consumers must use the local regulated Distribution Systems Operators (DSO's) who can own distribution and electricity generation assets. The electricity prices can vary significantly from region to region. The three biggest utilities; Axpo, Alpiq and BKW account for more than $80 \%$ of generation in Switzerland and in 2010 they were 85\% publicly owned (page 96 [59]). They are the largest shareholders of the Swissgrid, the Swiss transmission network operator and they also own the majority of PHES in Switzerland. Importantly, due to the high levels of interconnection with other countries, PHES in Switzerland can exploit price differentials between several markets. In particular nuclear electricity from France can provide cheap charging energy whilst electricity prices are generally higher in Italy [60]. In 2010 Switzerland's demand was approximately $60 \mathrm{TWh}$, while imports and exports were 66.6 TWh and 66.1 TWh respectively [59]. The average export price was 36.6\% higher than the import price. Public opinion of Swiss (pumped) hydro also seems to enjoy its branding as one of 'Europe's Green Batteries'.

Switzerland is one of two European countries which are currently building a significant capacity of new pumped storage (the other being Portugal), although it has to be noted that the market conditions for these plants have recently become less favorable as European spot market prices have become depressed and less volatile (especially in Germany as mentioned above). Plans for two other PHES plants with a combined capacity of 1,630 MW - BKW's Grimsel 3 and Repower's Lago Bianco - have been suspended [61].

\subsubsection{Japan}

Japan operates a partially liberalized electricity market which has not been fully unbundled; consumers with a connection size above $50 \mathrm{~kW}$ electrical are free to choose their supplier [31]. Below this size, consumers are still reliant on the their local market provider. Although the market has been open to Independent Power Producers (IPP's) since 1995, the General

Electricity Utilities operating in each region supply over $95 \%$ of the generation and are responsible for the transmission and distribution of electricity [62]. One reason for the low 
proportion of IPP's is the high transmission fees they face to use the local-monopoly-owned transmission infrastructure. These ten EPCO's are regional monopolies and privately owned vertically-integrated utilities [63]. Most of the PHES schemes in Japan are owned by these EPCO's and thus operate under a cost-of-service business model. Unlike in the unbundled markets of Europe and the USA therefore, there is no need to calculate how PHES plants will be individually profitable; the question instead is will they introduce an overall saving to the regional grid operator. Nearly $5 \mathrm{GW}$ of PHES is also owned by the wholesale electricity utility J-Power [9], which also owns $\sim 8.5 \mathrm{GW}$ of coal generation, as well as operating transmission infrastructure [64]. All PHES plants in Japan are owned by utilities with a mix of power generation and T/D infrastructure.

Since the Fukushima disaster in March 2011, Japanese energy policy has shifted radically to promote the use of renewable energies (through the introduction of subsidies) and lessen the dependence on nuclear energy generation [65]. The Japanese government has also approved further liberalization of the electricity market and unbundling of transmission and distribution from supply and generation [62]. It remains to be seen what the impact of these changes will be on EES developments in Japan.

\subsubsection{China}

The electricity market in China is partially liberalized; the vast majority of electricity infrastructure is owned by the state (including 95\% of installed PHES). Unbundling in 2002 entailed division of the State Power Corporation into two grid companies and five generation companies, with each remaining under state ownership [66]. Electricity generation has been opened to competition from IPP's; however electricity prices are not set through a competitive process. The government approves different electricity prices for individual projects based on average costs or a cost-plus system [67]. In this manner PHES schemes in China are operated under a number of different price mechanisms (as described by Ming et al. (2013) [34]). They can also be used as transmission and distribution assets. The majority of PHES schemes utilise either a single capacity-based payment or a Transmission/Distribution (T/D) tariff mechanism. Both of these payment mechanisms have 'cost-of-service' aspects and reflect the ancillary services value of the PHES station as well as its EES value and value as a transmission asset. 
In the single capacity-based price mechanism the PHES owner rents the scheme to the grid company for use. The grid company can then dispatch the PHES plant in the manner that provides most benefit to the system. The T/D tariff mechanism is used by PHES schemes that are owned by T/D companies. The grid companies provide the capital investment and their costs are covered by the prices charged to the end users under a T/D tariff. China is soon set to become the country with the largest installed capacity (power) of PHES (see Table 2); the government's target for 2020 is 50GW [34].

\subsubsection{USA}

In the USA, both (accounting) unbundled liberalised markets and partially-unbundled partially-liberalised markets exist. Around $66 \%$ of electricity consumed goes through markets that have undergone some restructuring [68]. In the unbundled liberalised markets bulk EES must compete for market services with other market participants (i.e. generators and demand response providers). In these pool-based markets, generators supply bids to the Independent System Operator (ISO) who schedules their operation to minimize the system operating costs. The generators specify a production cost, and the ISO schedules them to run when the market clearing price exceeds this value (see section 8.3.3 of [68]). PHES in the USA is at a disadvantage as storage must specify its own charging and discharging windows (as well as production costs) in the Day-Ahead (DA) market (using price forecasts), and the ISO then optimizes within that specified schedule. In effect this means that the charging and discharging bids are evaluated independently, putting storage at risk from making a loss. The exception to this is the PJM market which co-optimises the charging and discharging schedules on the DA market, by allowing the desired storage level at the end of the 24-hour period to be specified. However it does not allow for optimization in the Real-Time market [68]. The USA markets use locational marginal pricing rather than zonal pricing, therefore physical location must be taken into account when considering what services the PHES plant should offer. An extensive report by Koratorov et al. (2014) [68] looks at many aspects of PHES in the USA. The report highlights the value of PHES and its ability to lower the overall energy system costs. It notes that unbundled liberalised markets do not currently reward EES sufficiently given its potential benefits and cost of service type rewards offer a more stable revenue stream. However the report also notes that it is difficult for storage developers to quantify the value of EES in the 
partially unbundled USA markets due to a lack of transparency. Public opposition to PHES can also be a significant barrier, partly due to a lack of understanding of the benefits of energy storage [9].

In the liberalised markets, ancillary services can offer larger revenues to PHES operators than time-shifting energy (energy arbitrage). Ela et al. (2013) [69] investigates the value of ancillary services in five US market areas (California, Electric Reliability Council of Texas, New York, Midwest Independent System Operator, and New England) and states that market operators typically value regulation reserves the most, followed by spinning reserves (Table 82 in [68] shows ancillary service price information for these markets).

There have been some recent developments relevant to EES in USA electricity markets; for example FERC 755 requires that ISO's must compensate actual services provided for frequency response, noting that faster acting resources provide a greater degree of frequency regulation service. In response PJM, CAISO, MISO, NYISO, and NE-ISO have introduced "pay-for-performance" - a separate fast response tariff for regulation services available over relatively short timeframes [70]. Although this is technology neutral, it should favor PHES and other fast acting energy storage technologies. California recently became the first state to mandate a certain level of storage that is required to be in operation or under construction by 2020. The effect that this and other related policy developments in the USA will have on energy storage profitability is yet to be seen, although it is estimated that the California mandate has opened a market of \$3-5 billion [70].

\subsubsection{India}

India operates a partially liberalised electricity market - the WEMI. The Central Electricity Regulatory Commission (CERC) is currently in the process of promoting wholesale competition and open-access transmission. The central and state governments own the majority of generation in India, although the share owned by the private sector is increasing. In 2012 regional state governments owned $51 \%$ of the generation capacity in India, while the central government owned $33 \%$ and the private sector owned $16 \%$ [71]. There are four trading mechanisms in the WEMI; long-term bilateral contracts, short-term bilateral contracts, 
unscheduled interchange and the power exchanges. Over $90 \%$ of electricity is traded through long-term contracts [71]. Due to the deficit of peak electrical supply there is significant upward pressure on electricity prices. Transmission congestion, especially between the eastern-northern and eastern-western regions, also pushes up the market price. In its twelfth five year plan India plans to bring online more than $120 \mathrm{GW}$ of extra generation capacity, with over half of this being coal generation [72].

PHES plants in India generally enter into long term PPA's with state-owned utilities, who agree to supply off-peak electricity in return for peak-time electricity. Due to the undersupply of peak demand in India, a stable off-peak electricity price is yet to become well-defined. In addition, several open-loop PHES schemes in India are limited by the availability of water, as it is often needed for irrigation. The $1 \mathrm{GW}$ Tehri Pumped Storage Plant (PSP) is currently under-construction in the state of Uttarakhand. It is owned by Tehri Hydro Development Corporation India, a joint venture of the Indian Government and the State Government of Uttar Pradesh (UP) [37]. The pumping power will be provided by off-peak power from the beneficiary state utilities. The states are Delhi, Uttarakhand, Rajasthan and Haryana with whom power purchase agreements have already been agreed for the entire rated 1,000MW power. The states will, in turn, get proportionate peaking power from the PHES plant [73].

Table 4 shows a summary of the information contained in section 3.3. 
Table 4: summary of market mechanisms by country and example PHES plants

\begin{tabular}{|c|c|c|c|c|}
\hline Country & Market Type & T\&D owned? & Market mechanisms used & Example PHES project \\
\hline Great Britain & $\begin{array}{lll}\text { Liberalised } & \text { market, } & \text { ownership } \\
\text { unbundling } & & \\
\end{array}$ & No & $\begin{array}{l}\text { Competes for market services, utilities use for } \\
\text { internal trading }\end{array}$ & $\begin{array}{l}\text { Dinorwig. 1800MW, 9.1 GWh. Owned by First Hydro. } \\
\text { Provides frequency response, Short Term Operating } \\
\text { Reserve, peak capacity, blackstart }\end{array}$ \\
\hline USA & $\begin{array}{l}\text { Both liberalised and partially-liberalised } \\
\text { markets exist, with unbundling ranging } \\
\text { from accounting to none }\end{array}$ & $\begin{array}{l}\text { No in } \\
\text { liberalised } \\
\text { markets }\end{array}$ & $\begin{array}{l}\text { Competes for market services and used for internal } \\
\text { trading in competitive markets, cost-of-service } \\
\text { payment available in regulated markets although } \\
\text { lack of transparency }\end{array}$ & $\begin{array}{l}\text { Bath County Pumped Hydro. } 3030 \text { MW, } 24 \text { GWh. Owned } \\
\text { by Dominion Power (60\%) and FirstEnergy (40\%). } \\
\text { Provides peak capacity, electric time shift and reliability } \\
\text { services. }\end{array}$ \\
\hline Germany & Liberalised market and legal unbundling & No & $\begin{array}{l}\text { Competes for market services, utilities use for } \\
\text { internal trading }\end{array}$ & $\begin{array}{l}\text { Goldisthal Pumped Storage Power Station. } 1060 \mathrm{MW}, 8.5 \\
\text { GWh. Provides peak capacity, Voltage Support, } \\
\text { Frequency Regulation and Black Start services. First } \\
\text { European plant to include variable speed pumps. Owned } \\
\text { by Vattenfall. }\end{array}$ \\
\hline China & $\begin{array}{l}\text { Partially liberalised market, legal } \\
\text { unbundling }\end{array}$ & Yes & $\begin{array}{l}\text { Tariffs approved for individual projects based on } \\
\text { average costs or a cost-plus system (includes single } \\
\text { capacity based mechanism, T\&D tariff, two-part } \\
\text { price mechanism, single energy-based price } \\
\text { mechanism) }\end{array}$ & $\begin{array}{l}\text { Tianhuangping Pumped Storage Power Station. 1836MW, } \\
\sim 13 \text { GWh. Owned by East China Electric Power } \\
\text { (subsidiary SGCC). Used to stabilise power grid, improve } \\
\text { power supply quality in east China, and ensure safe grid } \\
\text { operation }\end{array}$ \\
\hline Japan & $\begin{array}{l}\text { Partially liberalised market, accounting } \\
\text { unbundling }\end{array}$ & Yes & Cost-of-service payments and market participation & $\begin{array}{l}\text { Okutataragi Pumped Storage Power Station. } 1932 \text { MW. } \\
\text { Used as a T\&D asset. Owned by Kansai Electric Power } \\
\text { Company. }\end{array}$ \\
\hline India & Competitive market, legal unbundling & Yes & $\begin{array}{l}\text { Competes in electricity market. Long term PPA's to } \\
\text { provide peak power. }\end{array}$ & $\begin{array}{l}\text { Tehri Pumped Storage Plant. } 1000 \text { MW. Provides peak } \\
\text { capacity. Being developed by THDC India, a joint venture } \\
\text { of the Indian Government and the State Government of } \\
\text { Uttar Pradesh }\end{array}$ \\
\hline Switzerland & Partially liberalised, legal unbundling & Yes & $\begin{array}{l}\text { Can exploit market prices in neighboring countries. } \\
\text { Competes for market services. Can be owned by a } \\
\text { distribution utility. }\end{array}$ & $\begin{array}{l}\text { Linth-Limmern Pumped Storage Scheme } \\
480 \mathrm{MW} \text {, (being expanded to } 1480 \mathrm{MW} \text { ). Provides electric } \\
\text { capacity. Owned by Axpo. }\end{array}$ \\
\hline
\end{tabular}




\section{Observations}

The previous sections have looked at the historical deployment of PHES and the ways in which it operates in different international electricity markets. In light of this review we make several observations:

- The countries that are currently seeing the largest PHES development are China, India, Switzerland and Japan. These countries all operate partially liberalised electricity markets in which PHES can be owned and operated by vertically integrated companies that also own and operate Transmission and Distribution infrastructure. The Swiss market most closely resembles the competitive markets of the USA and the EU, however it is also exceptional due to the high levels of interconnection with the liberalised markets of Germany, France, Italy and Austria. Despite this, Switzerland is feeling the effects of unfavourable European wholesale electricity prices (especially in the German market) and plans for two new large pumped storage schemes in Switzerland in the early stages of construction have been suspended [61].

- A significant proportion of the development of PHES in the review region is occurring in India and China, two countries with rapidly expanding economies and where peaktime electricity especially is in short supply. In these countries the PHES development is occurring alongside significant expansions of other new generating capacity [72] and in these regions there is no overcapacity of electricity generation, required either for energy purposes or flexibility to load-follow. The PHES plants in these countries are being developed by state-owned vertically-integrated utilities who own both generation and transmission assets [34], [37] and are remunerated in a regulated manner. It is significant that these organisations have valued PHES sufficiently highly to justify investment. The converse is true in much of Western Europe and the USA where in general, PHES operates in competitive market segments only, and sufficient generating capacity to meet peak demands are in place. Japan and Switzerland provide exceptions and are developing PHES despite having sufficient generation capacity to meet current demand levels, however their electricity markets are not fully unbundled. It is also worth noting that the lack of PHES development in Western Europe and the USA is despite concerns about maintaining supply and reserve margins with the phase-out of 
high emission coal plants in many European countries [8] (and nuclear power in Germany).

- Although existing PHES plants in the USA continue to operate, there has been very little PHES development in the USA since 1990. This is despite the presence of both unbundled liberalised electricity markets and markets with little or no unbundling, and potentially a large amount of further feasible sites available [9].

- In the unbundled liberalised electricity markets of the UK and Germany, large PHES plants tend to simultaneously participate in different electricity market services (i.e. frequency regulation services, electricity time-shift, electricity supply capacity, blackstart etc.). They can do this by using discrete independently functioning pumpturbine units that are connected to the same reservoirs, which can then bid for separate market services. In this way they may be able to reduce the risks associated with particular market mechanisms that have penalties for lack of service availability.

- It is possible for renewable subsidies to discourage the uptake of EES by artificially reducing wholesale peak electricity prices to the extent that energy storage operation becomes unprofitable. This can be further reinforced if the subsidies increase the margin between retail and wholesale electricity prices, which generates consumer hostility to any energy price increase and can in turn put downwards pressure on wholesale electricity prices. Energy storage subsidies may be able to provide the necessary economic motivations, although in a similar vein they may introduce perverse policy outcomes - just as renewable subsidies have for storage.

\section{Discussions}

It is found that most PHES was originally commissioned under the remit of publically owned vertically integrated utilities in monopoly markets - in the regions included in our study we find that only 4.9 GW of PHES was deployed in unbundled liberalised markets, out of a total of $117 \mathrm{GW}$. This is still the case today, wherein the majority of PHES development is by stateowned vertically-integrated utilities in the expanding economies of China and India. It seems likely that the value of PHES for these diverse organisations is sufficiently high to be worth investment, whereas this is not the case for utilities operating in just one market segment in unbundled markets, even if there is an increasing need for flexible assets in these markets. A 
major reason for this seems to be that vertically integrated utilities can accrue the benefits of their investments in PHES wherever they occur throughout the network value chain, i.e. the split-incentive problem is much reduced or negated. Accordingly, it is appropriate that less of a risk premium would be attached to the funding of such schemes, and so, the cost of capital should be cheaper too. In markets that have been unbundled and liberalised, it is unclear how best to deal with this split incentive problem to encourage new investments in bulk EES (assuming bulk EES would provide a wider societal benefit). Assuming a policy mechanism could be agreed to allow this split incentive problem to be better managed, this would undoubtedly benefit storage operators and thus provide a better investment landscape for bulk EES.

The risk of a changing regulatory environment that has an impact on electricity market prices is another factor that would drive up the weighted average cost of capital, as the revenue streams available from time-shifting energy to potential storage operators can change drastically from year to year [47]. It is therefore expected that private sector investment in bulk EES projects would happen in markets where there is a reduced risk in terms of future revenues as well as an appropriate rate of return. This could be the case when bulk EES investment is rewarded in a cost-of-service manner e.g. as a regulated transmission or distribution asset rather than as either electricity-generating or electricity-consuming entities.

However having bulk EES owned and operated by transmission and distribution companies does not necessarily lead to third party access (unless policy specifically directs this). It would be rational that any bulk EES would be operated in a manner that disproportionately benefits the owners and their non-competitive network businesses, at the expense of other stakeholders in the liberalised areas of the electrical supply system. For example, this could occur if a T\&D owned EES facility which was paid for by captive customers were also to be used in the competitive market [74]. Accordingly there is a risk that bulk EES will not create the widest social benefit and potential legislation needs to minimise this risk.

In the UK, the stated top-level aims of electrical energy policy are to create an affordable decarbonised electrical network with an appropriate degree of security of supply. If the advantages of bulk EES become increasingly clear to policy makers to facilitate a 2 
decarbonised system at a lower cost, and given that the UK treasury should be able to borrow money at a lower rate than private sector investors, it should ceteris paribus be able to commission a bulk EES scheme at a lower cost than a private sector equivalent. Indeed an article by Sundararagavan and Baker found that the interest rate was the factor that had the greatest impact on the annualised total storage cost for PHES [75]. Government ownership could also guarantee third party access in a manner suggested by the paper by Glachant and Xe [76] in terms of auctioning off the capacity of the PHES in various blocks.

\section{Conclusions}

This paper has provided an historical context of the development of the majority of globally installed Pumped Hydroelectric Energy Storage. It has given an overview of the mechanisms by which these EES plants interact with their respective electricity markets in the countries with the largest predicted growth of grid-scale energy storage - The Electricity Advisory Committee report for the US DOE states that the US, China, Japan, Germany, and the UK are expected to cover over two-thirds of the grid-scale EES market by 2017 [77].

It is clear that the majority of PHES development so far has occurred under public ownership and has been aligned with periods of significant electricity infrastructure growth. Considering that PHES is regarded as the technology of choice for historical bulk EES, it seems unlikely that other bulk EES technologies will fare significantly better in competitive wholesale electricity markets without very significant policy changes. This work suggests that, pending very significant changes in energy policy, bulk EES will struggle to promote private sector investment in unbundled deregulated markets. This is especially true when there are still significant levels of fuel-based generation providing system flexibility and a focus on promoting interconnectors to increase the size of markets. If however an increasing body of research concludes that bulk EES has a net societal benefit, a meaningful debate around public sector investment in bulk EES is merited.

As seen in Germany, renewable subsidies (without the incentive to produce a load-following output) have the potential to present a significant obstacle to PHES profitability. Rather than 
producing a cheap source of charging electricity they appear instead to have reduced the price spread of day-ahead wholesale prices making EES operation less and less profitable. This is despite the presence of several periods with negative electricity prices which increase the rewards for EES operators [78].

We do not suggest that bulk EES is the only or indeed the best form of electrical system flexibility, but conclude from this review that if policy makers decide that storage is to be one of their preferred options to provide electrical system flexibility, then the option for the public sector to commission the deployment of new bulk EES should be considered. This is in recognition that the vast majority of existing bulk EES were commissioned under the public sector. In liberalised markets however, we would also suggest that regardless of public sector commissioning and ownership, access to the storage scheme should be fully transparent, open to third parties and that this should be through some form of auctioning process. The ability of the public sector to invest in a long-lived electrical asset that is not exclusively a network asset, not a generator, and not a demand, but a combination of all three, and to make this available to the wider market through auctions is something that merits serious discussion, in order to provide bulk EES schemes at the lowest cost and least regulatory burden.

\section{Acknowledgements}

This work was supported by the Engineering and Physical Sciences Research Council under the grants EP/K002252/1 (Energy Storage for Low Carbon Grids) and EP/L014211/1 (Next Generation Grid Scale Thermal Energy Storage Technologies).

\section{References}

[1] I. A. G. Wilson, P. G. McGregor, and P. J. Hall, "Energy storage in the UK electrical network: Estimation of the scale and review of technology options," Energy Policy, vol. 38, no. 8, pp. 4099-4106, 2010.

[2] P. Denholm, E. Ela, B. Kirby, and M. Milligan, "The Role of Energy Storage with 
Renewable Electricity Generation,” 2010.

[3] J. Eyer and G. Corey, "Energy storage for the electricity grid: Benefits and market potential assessment guide," 2010.

[4] M. Beaudin, H. Zareipour, A. Schellenberglabe, and W. Rosehart, "Energy storage for mitigating the variability of renewable electricity sources: An updated review," Energy Sustain. Dev., vol. 14, no. 4, pp. 302-314, 2010.

[5] F. Steinke, P. Wolfrum, and C. Hoffmann, "Grid vs. storage in a 100\% renewable Europe," Renew. Energy, vol. 50, pp. 826-832, 2013.

[6] J. Cochran, L. Bird, J. Heeter, and D. J. Arent, "Integrating Variable Renewable Energy in Electric Power Markets : Best Practices from International Experience,” 2012.

[7] R. Gross, P. Heptonstall, M. Leach, D. Anderson, T. Green, and J. Skea, "Renewables and the grid: understanding intermittency," Proc. Inst. Civ. Eng. - Energy, no. February 2007, pp. 31-41, 2007.

[8] R. Laleman and J. Albrecht, "Nuclear and old fossil phase out scenarios: Assessment of shortages, surpluses and the load factor of flexible assets with high renewable generation targets - A Belgian case study," Int. J. Electr. Power Energy Syst., vol. 74, pp. 338-347, 2016.

[9] C. Yang and R. B. Jackson, "Opportunities and barriers to pumped-hydro energy storage in the United States," Renew. Sustain. Energy Rev., vol. 15, no. 1, pp. 839-844, Jan. 2011.

[10] Y. Li, H. Cao, S. Wang, Y. Jin, D. Li, X. Wang, and Y. Ding, "Load shifting of nuclear power plants using cryogenic energy storage technology," Appl. Energy, vol. 113, pp. 1710-1716, 2014.

[11] V. Scott, S. Gilfillan, N. Markusson, H. Chalmers, and R. S. Haszeldine, "Last chance for carbon capture and storage," Nat. Clim. Chang., vol. 3, no. 2, pp. 105-111, 2013.

[12] X. Luo, J. Wang, M. Dooner, and J. Clarke, "Overview of current development in electrical energy storage technologies and the application potential in power system operation," Appl. Energy, vol. 137, pp. 511-536, 2015.

[13] H. S. Chen, T. N. Cong, W. Yang, C. Q. Tan, Y. L. Li, and Y. L. Ding, "Progress in 
electrical energy storage system: A critical review," Prog. Nat.Sci., vol. 19, no. 3, pp. 291-312, 2009.

[14] T. Stanton, "Envisioning State Regulatory Roles in the Provision of Energy Storage.," 2014. [Online]. Available: http://energystorage.org/system/files/resources/nrri_1408_energy_storage.pdf. [Accessed: 05-Jan-2016].

[15] N. S. Wade, P. C. Taylor, P. D. Lang, and P. R. Jones, "Evaluating the benefits of an electrical energy storage system in a future smart grid," Energy Policy, vol. 38, no. 11, pp. 7180-7188, 2010.

[16] G. Grazzini and A. Milazzo, “A Thermodynamic Analysis of Multistage Adiabatic CAES," Proc. Ieee, vol. 100, no. 2, pp. 461-472, 2012.

[17] B. Dunn, H. Kamath, and J. Tarascon, "Electrical energy storage for the grid: a battery of choices," Science (80-. )., vol. 928, no. 2011, 2011.

[18] A. Z. Weber, M. M. Mench, J. P. Meyers, P. N. Ross, J. T. Gostick, and Q. H. Liu, "Redox flow batteries: a review," J. Appl. Electrochem., vol. 41, no. 10, pp. 1137-1164, 2011.

[19] Centre for Low Carbon Futures and Liquid Air Energy Network, "Liquid Air Technologies - a guide to the potential," 2013. [Online]. Available: http://www.lowcarbonfutures.org/sites/default/files/potential-guide.pdf. [Accessed: 05Jan-2016].

[20] T. Desrues, J. Ruer, P. Marty, and J. F. Fourmigue, “A thermal energy storage process for large scale electric applications," Appl. Therm. Eng., vol. 30, no. 5, pp. 425-432, 2010 .

[21] J. Andrews and B. Shabani, "Re-envisioning the role of hydrogen in a sustainable energy economy," Int. J. Hydrogen Energy, vol. 37, no. 2, pp. 1184-1203, 2012.

[22] F. Crotogino, K. U. Mohmeyer, and R. Scharf, "Huntorf CAES: More than 20 years of successful operation," in Solution Mining Research Institute Meeting, Orlando, FL, 2325 April, 2001.

[23] M. Nakhamkin and M. Chiruvolu, “Available Compressed Air Energy Storage (CAES) Plant Concepts,” 2007. [Online]. Available: 
http://espcinc.com/library/PowerGen_2007_paper.pdf. [Accessed: 05-Jan-2016].

[24] O. H. Anuta, P. Taylor, D. Jones, T. McEntee, and N. Wade, “An international review of the implications of regulatory and electricity market structures on the emergence of grid scale electricity storage," Renew. Sustain. Energy Rev., vol. 38, pp. 489-508, Oct. 2014.

[25] J. P. Deane, B. P. Ó Gallachóir, and E. J. McKeogh, "Techno-economic review of existing and new pumped hydro energy storage plant," Renew. Sustain. Energy Rev., vol. 14, no. 4, pp. 1293-1302, May 2010.

[26] C. J. Yang, "Pumped hydroelectric storage: Technical report," 2010. [Online]. Available: http://people.duke.edu/ cy42/PHS.pdf. [Accessed: 01-May-2016].

[27] CIA, "Country Comparison: Electricity - installed generating capacity, The World Factbook," 2013. [Online]. Available: https://www.cia.gov/library/publications/theworld-factbook/rankorder/2236rank.html. [Accessed: 01-May-2016].

[28] Sandia National Laboratories, "DOE Global Energy Storage Database." [Online]. Available: http://www .energystorageexchange.org/. [Accessed: 01-May-2016].

[29] "Energy Storage Sense," 2015. [Online]. Available: Www .energystoragesense.com/downloads. [Accessed: 16-Jun-2015].

[30] "Iberdrola completes work on Europe's largest pumped-storage project," Hydroworld.com, 2013. [Online]. Available: http://www.hydroworld.com/articles/2013/10/iberdrola-completes-work-on-europe-slargest-pumped-storage-project.html. [Accessed: 05-Jan-2016].

[31] The Federation of Electric Power Companies, "Electricity Review Japan,” 2014. [Online]. Available: http://www.fepc.or.jp/library/pamphlet/pdf/2014ERJ_full.pdf. [Accessed: 16-Jun-2015].

[32] “Okinawa Seawater Pumped Storage Power Plant.” [Online]. Available: http://www.ieahydro.org/reports/Annex_VIII_CaseStudy0101_Okinawa_SeawaterPS_J apan.pdf. [Accessed: 01-May-2016].

[33] A. Poullikkas, "A comparative overview of large-scale battery systems for electricity storage,” Renew. Sustain. Energy Rev., vol. 27, pp. 778-788, 2013. 
[34] Z. Ming, Z. Kun, and L. Daoxin, "Overall review of pumped-hydro energy storage in China: Status quo, operation mechanism and policy barriers," Renew. Sustain. Energy Rev., vol. 17, pp. 35-43, Jan. 2013.

[35] Global Wind Energy Council, "Global wind report annual market update," 2013. [Online]. Available: http://www.gwec.net/wp-content/uploads/2014/04/GWEC-GlobalWind-Report_9-April-2014.pdf. [Accessed: 01-May-2016].

[36] International Hydropower Association, "China HydroPower Statistics," 2014. [Online]. Available: http://www.hydropower.org/country-profiles/china. [Accessed: 16-Jun-2015].

[37] N. Sivakumar, D. Das, N. P. Padhy, a. R. Senthil Kumar, and N. Bisoyi, "Status of pumped hydro-storage schemes and its future in India," Renew. Sustain. Energy Rev., vol. 19, pp. 208-213, Mar. 2013.

[38] B. R. D. Masiello, B. Roberts, and T. Sloan, "Business Models for Deploying and Operating Energy Storage and Risk Mitigation Aspects," Proc. IEEE, vol. 102, no. 7, 2014.

[39] D. S. Kirschen and G. Strbac, “ Fundamentals of Power System Economics, 2004 :Wiley." Wiley, 2004.

[40] P. del Río and P. Mir-Artigues, "Combinations of support instruments for renewable electricity in Europe: A review," Renew. Sustain. Energy Rev., vol. 40, pp. 287-295, 2014.

[41] R. Haas, G. Resch, C. Panzer, S. Busch, M. Ragwitz, and A. Held, "Efficiency and effectiveness of promotion systems for electricity generation from renewable energy sources - Lessons from EU countries," Energy, vol. 36, no. 4, pp. 2186-2193, 2011.

[42] J. Albrecht, R. Laleman, and E. Vulsteke, "Balancing demand-pull and supply-push measures to support renewable electricity in Europe," Renew. Sustain. Energy Rev., vol. 49, pp. 267-277, 2015.

[43] T. Bayar, "Solar Storage Market Set for Rapid Growth,” 2013. [Online]. Available: http://www.renewableenergyworld.com/rea/news/article/2013/03/solar-storage-marketset-for-rapid-growth?cmpid=rss. [Accessed: 16-Jun-2015].

[44] P. Taylor, R. Bolton, D. Stone, and P. Upham, "Developing pathways for energy 
storage in the UK using a coevolutionary framework," Energy Policy, vol. 63, pp. 230243, 2013.

[45] T. Das, V. Krishnan, and J. D. McCalley, "Assessing the benefits and economics of bulk energy storage technologies in the power grid," Appl. Energy, vol. 139, pp. 104$118,2015$.

[46] International Power First Hydro, "Introduction to First Hydro," 2010. [Online]. Available: http://www.iprplc-gdfsuez.com/ /media/Files/I/IPRPlc/Attachments/presentations-pdfs/2010/first-hydro-IPR-investor-visit. [Accessed: 01May-2016].

[47] E. Barbour, I. A. G. Wilson, I. G. Bryden, P. G. McGregor, P. A. Mulheran, and P. J. Hall, "Towards an objective method to compare energy storage technologies: development and validation of a model to determine the upper boundary of revenue available from electrical price arbitrage," Energy Environ. Sci., vol. 5, no. 1, pp. 54255436, 2012.

[48] D. Connolly, H. Lund, P. Finn, B. V. Mathiesen, and M. Leahy, "Practical operation strategies for pumped hydroelectric energy storage (PHES) utilising electricity price arbitrage," Energy Policy, vol. 39, no. 7, pp. 4189-4196, Jul. 2011.

[49] BBC News, "Scottish government approves £800m Lochaber hydro scheme." [Online]. Available: http://www.bbc.com/news/uk-scotland-highlands-islands-25365786. [Accessed: 16-Jun-2015].

[50] National Grid, “Firm Frequency Response Tender Report - November 2014,” 2014. [Online]. Available: http://www.nationalgrid.com/uk/Electricity/Balancing/services/frequencyresponse/ffr. [Accessed: 16-Jun-2015].

[51] N. Lannen, "SSE Renewables: New Pumped Storage Proposals," 2011. [Online]. Available: http://www.theiet.org/communities/powergen/all-energy/pumpedstorage.cfm?type=pdf. [Accessed: 16-Jun-2015].

[52] Scottish and Southern Energy (SSE), "Coire Glas Hydro Scheme," 2015. [Online]. Available: http://sse.com/whatwedo/ourprojectsandassets/renewables/CoireGlas/. [Accessed: 16-Jun-2015]. 
[53] B. Burger, "Electricity production from solar and wind in Germany in 2014," 2014. [Online]. Available: www.ise.fraunhofer.de. [Accessed: 16-Jun-2015].

[54] B. Steffen, "Prospects for pumped-hydro storage in Germany," Energy Policy, vol. 45, pp. 420-429, Jun. 2012.

[55] S. Brick, "The Integrated Grid and Decarbonization: The Case for Systems Thinking," 2014. [Online]. Available: http://www.epri.com/AboutUs/Documents/Summer_Seminar_2014/Session 3.4_Brick_FINAL.pdf. [Accessed: 16Jun-2015].

[56] K. Bruninx, D. Madzharov, E. Delarue, and W. D'haeseleer, "Impact of the German nuclear phase-out on Europe's electricity generation-A comprehensive study," Energy Policy, vol. 60, pp. 251-261, 2013.

[57] Voith, "Goldisthal, Germany." [Online]. Available: http://www.voith.com/en/marketsindustries/industries/hydro-power/pumped-storage-plants/goldisthal_main-98799879.html. [Accessed: 16-Jun-2015].

[58] P. Ochoa and A. van Ackere, "Policy changes and the dynamics of capacity expansion in the Swiss electricity market," Energy Policy, vol. 37, no. 5, pp. 1983-1998, 2009.

[59] International Energy Agency, “Energy Policies of IEA Countries, Switzerland (2012) Review.," 2012. [Online]. Available: http://www.iea.org/publications/freepublications/publication/energy-policies-of-ieacountries---switzerland-2012-review.html. [Accessed: 01-May-2016].

[60] E. Pellini, "Measuring the impact of market coupling on the Italian electricity market," Energy Policy, vol. 48, pp. 322-333, 2012.

[61] Reuters, "Cavernous Swiss power plant undermined by renewable energy." [Online]. Available: http://www.reuters.com/article/2014/08/31/utilities-swiss-pumpedstorageidUSL5N0QV3FK20140831. [Accessed: 16-Jun-2015].

[62] T. Yamazaki, “Electricity Market Reform in Japan,” 2013. [Online]. Available: http://www.eu-japan.eu/sites/eu-japan.eu/files/Session2_Yamazaki.pdf. [Accessed: 01May-2016].

[63] H. Asano, "Regulatory reform of the electricity industry in Japan: What is the next step 
of deregulation?," Energy Policy, vol. 34, no. 16, pp. 2491-2497, Nov. 2006.

[64] A. Haarscher, M. Bruner, J. Doblas, A. Fargere, S. F. Ashley, and W. J. Nuttall, “The Japanese Electricity System 15 months After March 11th 2011," University of Cambridge Energy Policy Research Group. [Online]. Available: http://www.eprg.group.cam.ac.uk/wp-content/uploads/2014/10/1417-PDF.pdf. [Accessed: 01-May-2016].

[65] M. Hayashi and L. Hughes, "The policy responses to the Fukushima nuclear accident and their effect on Japanese energy security,” Energy Policy, vol. 59, pp. 86-101, 2013.

[66] B. S. Yeoh and R. Rajaraman, "Electricity in China: The latest reforms," Electr. J., vol. 17, no. 3, pp. 60-69, 2004.

[67] J. Ma, "On-grid electricity tariffs in China: Development, reform and prospects," Energy Policy, vol. 39, no. 5, pp. 2633-2645, May 2011.

[68] V. Koritarov, V; Veselka, T; Gasper, J; Bethke, B; Botterud, A; Wang, J; Mahalik, M; Zhou, Z; Milostan, C; Feltes, J; Kazachkov, Y; Guo, T; Liu, G; Trouille, B; Donalek, P; King, K; Ela, E; Kirby, B; Krad, I; Gevorgian, "Modeling and Analysis of Value of Advanced Pumped Storage Hydropower in the U.S.," Argonne National Laboratory, 2014.

[69] E. Ela, B. Kirby, A. Botterud, C. Milostan, I. Krad, and V. Koritarov, "Role of Pumped Storage Hydro Resources in Electricity Markets and System Operation," in HydroVision International Denver, Colorado, July 23-26, 2013, 2013, no. May, pp. 112.

[70] M. Kintner-Meyer, "Regulatory policy and markets for energy storage in North America," Proc. IEEE, vol. 102, no. 7, pp. 1065-1072, 2014.

[71] U. K. Shukla and A. Thampy, "Analysis of competition and market power in the wholesale electricity market in India," Energy Policy, vol. 39, no. 5, pp. 2699-2710, May 2011.

[72] US Energy Information Administration, "India," 2014. [Online]. Available: http://www .eia.gov/countries/analysisbriefs/India/india.pdf. [Accessed: 16-Jun-2015].

[73] PowerTechnology.com, “Tehri Pumped Storage Plant, India,” 2014. [Online]. Available: 
http://www.power-technology .com/projects/tehri-pumped-storage-plant/. [Accessed: 01-May-2016].

[74] D. Bhatnagar, A. Currier, J. Hernandez, O. Ma, and B. Kirby, "MARKET AND POLICY BARRIERS TO ENERGY STORAGE DEPLOYMENT: A Study for the Energy Storage Systems Program,” Sandia National Laboratories, 2013.

[75] S. Sundararagavan and E. Baker, "Evaluating energy storage technologies for wind power integration," Sol. Energy, vol. 86, no. 9, pp. 2707-2717, 2012.

[76] X. He, E. Delarue, W. D'haeseleer, and J. M. Glachant, "A novel business model for aggregating the values of electricity storage," Energy Policy, vol. 39, no. 3, pp. 1575$1585,2011$.

[77] Electricity Advisory Committee, "2012 Storage Report : Progress and Prospects Recommendations for the U . S . Department of Energy,” 2012.

[78] E. Barbour, G. Wilson, P. Hall, and J. Radcliffe, "Can negative electricity prices encourage inefficient electrical energy storage devices?," Int. J. Environ. Stud., no. November, pp. 1-15, 2014. 